\title{
PENGARUH KEPEMIMPINAN ISLAM, KOMPENSASI, DAN PENGEMBANGAN PRODUK TERHADAP KINERJA KARYAWAN BANK PEMBIAYAAN RAKYAT SYARI'AH BANDAR LAMPUNG
}

\author{
Norfa Maliarosa Hasibuan \\ Pascasarjana UIN Raden Intan Lampung \\ norfahasibuan@gmail.com
}

\begin{abstract}
This study aims to examine the influence of Islamic leadership, compensation, and product development to improve employee performance. This research took place in Syari'ah Financing Bank. The sample used in this study was 60 respondents consisting of customers and employees. Data analysis used multiple linear regression analysis. The results showed that Islamic leadership, compensation, and product development were partially not a positive effect on employee performance, but simultaneously had a positive effect on employee performance. Islamic leadership, compensation dan product development had $45.5 \%$ effect employee performance, while $55.5 \%$ influence by other variables.
\end{abstract}

Keyword: Islamic Leadership, Compensation, Product Development, Performance

\begin{abstract}
ABSTRAK
Penelitian ini bertujuan untuk menguji pengaruh kepemimpinan Islam, kompensasi, dan pengembangan produk untuk meningkatkan kinerja karyawan. Penelitian ini dilakukan pada Bank Pembiayaan Rakyat Syari'ah Bandar Lampung. Sampel yang digunakan dalam penelitian ini 60 responden terdiri dari nasabah dan karyawan. Analisis data yang digunakan analisis regresi linier berganda. Hasil penelitian menunjukan bahwa kepemimpinan Islam, kompensasi, dan pengembangan produk secara parsial tidak berpengaruh positif terhadap kinerja karyawan, namun secara simultan berpengaruh positif terhadap kinerja karyawan. Variabel independen yang terdiri dari kepemimpinan Islam, kompensasi, dan pengembangan produk berpengaruh terhadap variabel dependen yaitu kinerja karyawan sebesar $45,5 \%$ kemudian sisanya dipengaruhi oleh variabel lain yang tidak digunakan dalam penelitian ini sebesar $55,5 \%$.
\end{abstract}

Kata Kunci : Kepemimpinan Islam, Kompensasi, Pengembangan Produk, Kinerja

\section{PENDAHULUAN}

Kinerja karyawan yang didefinisikan oleh Rivai dala (M. Shandy:2015) menjelaskan bahwa kinerja karyawan adalah hasil kerja atau prestasi yang dimiliki seorang karyawan dalam waktu tertentu dicapai dari melaksanakan tugas sesuai dengan tanggung jawab yang dimilikinya. Selain itu Amstrong dan Baron dalam (Abdullah:2014) mengatakan bahwasanya kinerja karyawan merupakan 
hasil yang dicapai individu dalam melaksanakan pekerjaan yang berhubungan kuat dengan strategi, kepuasan konsumen, dan berkontribusi bagi perekonomian.

Kinerja karyawan pada suatu perusahaan dapat terlihat pada tercapainya tujuan dan target perusahaan, dapat dilihat berdasarkan laporan keuangan juga laporan non keuangan. Laporan non keuangan dapat dilihat pencapain prestasi perusahaan yang dilihat dari award perusahaan, dalam mencapai award pasti diperlukan pengolahan sumber daya manusia yang berbeda, dalam hal ini pimpinan dan karyawan perusahaan. Kinerja karyawan dapat mengalami peningkatan dan penurunan disebabkan oleh beberapa faktor. Sebagai umat muslim tentu kita akan mempertanggungjawabkan semua yang kita lakukan diakhirat kelak, sehingga sebagai umat islam kita dituntut untuk melaksanakan pekerjaan sesuai perintah Allah SWT, dalam hal kinerja kita dituntut untuk memiliki gaya kepemimpinan Islam untuk mencapai kinerja yang baik.

Ratna Wijayanti (2016) mengungkapkan bahwa faktor pendukung yang dapat mempengaruhi kinerja karyawan yaitu kepemimpinan Islam, hal ini terjadi karena karyawan merasa diarahkan dengan adanya pimpinan ditengah mereka yang bukan hanya berorientasi pada pekerjaan tetapi juga pada kedekatan emosional terhadap karyawan. Fina Nafhatul Ithri dan Hendry Cahyono (2018) menjelaskan bahwa kepemimpinan Islam salah satu faktor penting dalam mencapai kinerja karyawan yang baik, dimana karyawan yang baik akan berdamapak pada kinerja perusahaan dengan tercapainya target dan tujuan perusahaan. Sebagaimana yang dijelaskan oleh Ary Gynanjar dalam bukunya ESQ (Emotional Spiritual Quetion) menerangkan bahwasanya seorang pemimpin yang baik dapat diterima oleh karyawan sehingga dapat dengan mudah mempengaruhi karyawan dalam bekerja, juga dapat menerapkan konsep keadilan dan tidak semena-mena dalam memimpin perusahaan.

Kepemimpinan yang dijelaskan merupakan kepemimpinan Islam, dimana seorang pemimpin bersifat sebagai penengah. Memegang konsep keadilan dan tidak berat sebelah antara hak dan kewajiban, juga konsep kesederhanaan, sehingga pemimpin dapat menempatkan dan memposisikan 
dirinya di tengah-tengah karyawan, bukan hanya pemimpin yang dapat memberikan perintah saja tetapi juga yang dapat menjadi suri tauladan bagi karyawan.

Annisa Coriyani Kwarimah dkk (2018) mendeskripsikan bahwa kepemimpinan merupakan faktor penting yang harus dimiliki oleh perusahaan untuk meningkatkan kinerja karyawan yang baik, namun meski demikian terdapat faktor lain yang juga harus dimiliki perusahaan untuk meningkatkan kinerja karyawannya. Sebagaimana yang diungkapkan oleh Zulhadi (2017) bahwa faktor yang harus dimiliki perusahaan selain kepemimpinan Islal ialah kompensasi, kompensasi merupakan faktor yang harus diperhatikan untuk menciptakan kinerja karyawan yang baik. Pemberian kompensasi yang sesuai diharapkan dapat menghasilkan kinerja karyawan yang baik juga.

Kompensasi menurut Hasibuan Malayu merupakan segala bentuk balas jasa yang diberikan perusahaan kepada karyawan berupa material dan immaterial baik yang dapat dimanfaatkan secara langsung ataupun tidak langsung. Kompensasi yang baik diharapkan dapat meningkatkan kinerja karyawan, pemberian kompensasi harus adil dan wajar sehingga setiap karyawan akan mendapatkan haknya sesuai dengan kewajiban yang telah dikerjakannya. Jesslyn Halim dan Fransisca Andreani (2017) dan Anik Irawati (2018) mengungkapkan hal berbeda dengan Zulhadi ia berpendapat bahwa kompensasi tidak memiliki pengaruh yang positif terhadap kinerja karyawan, kompensasi yang merupakan balas jasa atas prestasi yang dicapai karyawan untuk dirnya dan juga berdamapak pada perusahaan tidak memberikan pengaruh yang positif terhadap kinerja karyawan. Dikarenakan terdapat individu yang memiliki kinerja tinggi karena mengharapkan kompensasi, namun juga terdapat individu yang berkinerja tinggi dipengaruhi oleh faktor lainnya.

Felangga Al Yuzika dan Nurul Kholifah (2017) mnggungkapkan bahwa pengembangan inovasi produk dibutuhkan untuk meningkatkan minat nasabah, pengembangan produk perlu dilakukan perusahaan, baik terhadap produk yang telah ada ataupun belum ada. Dalam mengembangkan produk perusahaan diperlukan kinerja karyawan yang baik untuk memasarkan 
produk baru, dengan adanya produk baru diharapkan karyawan akan bekerja lebih keras demi tercapainya tujuan perusahaan.

Pengembangan produk menurut Philip Kottler dan Kevin Lane Keller merupakan strategi yang dilakukan perusahaan untuk menawarkan produk baru guna untuk perkembangan perusahaan. Charles $\mathrm{W}$ dkk pengembangan prosuk merupakan strategi pemasaran dalam menciptakan produk baru yang dapat diterima oleh pasar, bisa perubahan aplikasi teknologi atau penawaran produk baru. Dalam perusahaan pengembangan produk perlu untuk dilakukan dalam jangka waktu tertentu untuk memperbarui produk yang ada dan menghindari kejenuhan nasabah terhadap produk. Wahjuni (2017) menemukan bahwa inovasi produk perlu untuk dilakukan oleh perusahaan, dikarenakan produkproduk yang ada di pasaran akan membuat nasabah bosan, disebabkan karena perubahan selera konsumen di pasar. Berdasarkan pada uraian diatas didapatkan hipotesis sebagai berikut :

H1 : terdapat pengaruh anta akepemimpinan Islam terhadap kinerja karyawan secara parsial

H2 : terdapat pengaruh antaa kompensasi terhadap kinerja karyawan secara parsial

H3 : terdapat pengaruh antaa pengembangan produk terhadap kinerja karyawan secara parsial H4 : terdapat pengaruh antaa kepemimpinan Islam, kompensasi, dan pengembangan produk terhadap kinerja karyawan secara simultan.

\section{METODE PENELITIAN}

Metode penelitian yang digunakan pada penelitian ini metode penelitian kuantitatif. Dengan data primer yang didapatkan dari angket yang disebarkan kepada 60 responden terdiri dari 30 karyawan dan 30 nasabah Bank Pembiayaan Rakyat Syari'ah Bandar Lampung. Alat ukur yang digunakan angket berisi pernyataan dengan skala likert. Peneliti menggunakan metode analisis regresi linier berganda dan uji hipotesis dengan uji t, uji f, dan uji r, juga melakukan uji normalitas dan uji linieritas. 


\section{HASIL}

Berdasarkan hasil uji normalitas dapat dilihat bahwa uji normalitas Kolmogorov Smirnov memiliki nilai sebesar 0.743 . Hal ini menunjukan bahwa data yang digunakan dalam penelitian ini berdistribusi normal. Berdasarkan hasil uji linieritas maka dapat kita ketahui hasil dari uji linieritas antara variabel independent dan variabel dependen dalam penelitian ini sebagai berikut:

1) Terdapat hubungan linieritas antara variabel Kepemimpinan Islam terhadap kinerja karyawan, hal ini dapat dilihat bahwa nilai sig. Deviation from linearity sebesar 0,18 $>0,05$.

2) Terdapat hubungan linieritas antara variabel kompensasi terhadap kinerja karyawan, hal ini dapat dilihat bahwa nilai sig. Deviation from linearity sebesar $0,06>0,05$.

3) Terdapat hubungan linieritas antara variabel pengembangan produk terhadap kinerja karyawan, hal ini dapat dilihat bahwa nilai sig. Deviation from linearity sebesar 0, $94>0,05$.

Tabel 1. Uji Normalitas

\begin{tabular}{|c|c|c|}
\hline & & $\begin{array}{c}\text { Unstandardized } \\
\text { Residual } \\
\end{array}$ \\
\hline $\mathrm{N}$ & & 30 \\
\hline \multirow[t]{2}{*}{ Normal Parameters ${ }^{\mathrm{a}, \mathrm{b}}$} & Mean & .0000000 \\
\hline & Std. Deviation & 1.83695516 \\
\hline Most Extreme & Absolute & .124 \\
\hline \multirow[t]{2}{*}{ Differences } & Positive & .124 \\
\hline & Negative & -.109 \\
\hline Test Statistic & & .681 \\
\hline Asymp. Sig. (2-Tailed) & & .743 \\
\hline a. Test distribution of & Normal & \\
\hline b. Calculated from data & & \\
\hline c. Liliofers Significan & Correction & \\
\hline d. This is lower bound & Of the true sig. & \\
\hline
\end{tabular}

Tabel 2. Uji Linearitas 
ANOVA Table

\begin{tabular}{|c|c|c|c|c|c|c|c|}
\hline & & & Sum of $S$ & Df & $\begin{array}{l}\text { Mean } \\
\text { Square }\end{array}$ & $\mathrm{F}$ & \\
\hline \multirow{5}{*}{$\begin{array}{l}\text { Kepemimpinan } \\
\text { Islam * Kinerja } \\
\text { Karyawan }\end{array}$} & \multirow{3}{*}{$\begin{array}{l}\text { Between } \\
\text { a Groups }\end{array}$} & (Combined) & 115.908 & 12 & 9.659 & 2.588 & .036 \\
\hline & & Linearity & 49.981 & 1 & 49.981 & 13.390 & .002 \\
\hline & & $\begin{array}{l}\text { Deviation } \\
\text { Linearity }\end{array}$ & from 65.927 & 11 & 5.993 & 1.606 & .184 \\
\hline & \multicolumn{2}{|c|}{ Within Groups } & 63.458 & 17 & 3.733 & & \\
\hline & \multicolumn{2}{|l|}{ Total } & 179.367 & 29 & & & \\
\hline \multirow{5}{*}{$\begin{array}{l}\text { KOmpensasi } \\
\text { Kinerja } \\
\text { Karyawan }\end{array}$} & \multirow{3}{*}{$\begin{array}{l}* \text { Between } \\
\text { Groups }\end{array}$} & (Combined) & 147.075 & 18 & 8.171 & 2.783 & .044 \\
\hline & & Linearity & 24.518 & 1 & 24.518 & 8.352 & .015 \\
\hline & & $\begin{array}{l}\text { Deviation } \\
\text { Linearity }\end{array}$ & from 122.557 & 17 & 7.209 & 2.456 & .067 \\
\hline & \multicolumn{2}{|c|}{ Within Groups } & 32.292 & 11 & 2.936 & & \\
\hline & \multicolumn{2}{|l|}{ Total } & 179.367 & 29 & & & \\
\hline \multirow{5}{*}{$\begin{array}{l}\text { Pengembangan } \\
\text { Produk * Kinerja } \\
\text { Karyawan }\end{array}$} & \multirow{3}{*}{$\begin{array}{l}\text { Between } \\
\text { a Groups }\end{array}$} & (Combined) & 133.138 & 16 & 8.321 & 2.340 & .064 \\
\hline & & Linearity & 79.205 & 1 & 79.205 & 22.273 & .000 \\
\hline & & $\begin{array}{l}\text { Deviation } \\
\text { Linearity }\end{array}$ & from 53.933 & 15 & 3.596 & 1.011 & .497 \\
\hline & \multicolumn{2}{|c|}{ Within Groups } & 46.229 & 13 & 3.556 & & \\
\hline & \multicolumn{2}{|l|}{ Total } & 179.367 & 29 & & & \\
\hline
\end{tabular}

Berdasarkan hasil olah data menggunakan SPSS Versi 23 didapat hasil uji regresi linier berganda sebagai berikut.

Tabel 3. Analisis Regresi Linier Berganda 


\section{Coefficients $^{\mathrm{a}}$}

\begin{tabular}{|c|c|c|c|c|c|c|}
\hline \multirow[b]{2}{*}{ Model } & & \multicolumn{2}{|c|}{$\begin{array}{l}\text { Unstandardized } \\
\text { Coefficients }\end{array}$} & \multirow{2}{*}{$\begin{array}{l}\text { Standardized } \\
\text { Coefficients } \\
\text { Beta }\end{array}$} & \multirow[b]{2}{*}{$\mathrm{t}$} & \multirow[b]{2}{*}{ Sig. } \\
\hline & & B & Std. Error & & & \\
\hline 1 & (Constant) & 5.036 & 3.085 & & 1.632 & .115 \\
\hline & $\begin{array}{l}\text { Kepemimpinan } \\
\text { Islam }\end{array}$ & .079 & .218 & .078 & .360 & .722 \\
\hline & Kompensasi & .066 & .125 & .090 & .528 & .602 \\
\hline & $\begin{array}{l}\text { Pengembangan } \\
\text { Produk }\end{array}$ & .546 & .196 & .572 & 2.787 & .010 \\
\hline
\end{tabular}

Maka didapatkan persamaan regresi sebagai berikut $Y=\mathbf{5 . 0 3 6}+\mathbf{0 , 0 7 9} \times \mathbf{x}+\mathbf{0 . 0 6 6} \times \mathbf{x}+\mathbf{0 , 5 4 6} \times \mathbf{3}+\mathbf{e}$.

Berdasarkan tabel hasil uji F/simultan yang telah dilakukan maka didapat nilai $\mathrm{F}$ sebesar 7,219 dengan signifikansi 0,001. Nilai $F$ hitung lebih besar dari nilai $F$ tabel yaitu 7.219 $>3,340$ sehingga disimpulkan bahwa secara simultan terdapat pengaruh antara kepemmpinan Islam, kompensasi, dan pengembangan produk terhadap kinerja karyawan. 
Tabel 4. Hasil uji F

ANOVA $^{b}$

\begin{tabular}{|c|c|c|c|c|c|}
\hline & Sum & ff & & & \\
\hline Model & Squares & Df & Mean Square & $\mathrm{F}$ & Sig. \\
\hline Regression & 81.509 & 3 & 27.170 & 7.219 & $.001^{\mathrm{a}}$ \\
\hline Residual & 97.858 & 26 & 3.764 & & \\
\hline Total & 179.367 & 29 & & & \\
\hline
\end{tabular}

Berdasarkan pada tabel hasil uji t didapatkan pengaruh negatif kepemimpinan Islam, kompensasi, dan pengembangan produk terhadap kinerja karyawan secara parsial. Tabel dapat dilihat dibawah ini:

Tabel 5. uji T/parsial Coefficients $^{\mathrm{a}}$

\begin{tabular}{|c|c|c|c|c|c|c|}
\hline & & \multicolumn{2}{|c|}{$\begin{array}{l}\text { Unstandardized } \\
\text { Coefficients } \\
\end{array}$} & \multirow{2}{*}{$\begin{array}{l}\text { Standardized } \\
\text { Coefficients } \\
\text { Beta }\end{array}$} & \multirow[b]{2}{*}{$\mathrm{t}$} & \multirow[b]{2}{*}{ Sig. } \\
\hline \multicolumn{2}{|c|}{ Model } & $\mathrm{B}$ & Std. Error & & & \\
\hline \multirow[t]{4}{*}{1} & (Constant) & 5.036 & 3.085 & & 1.632 & .115 \\
\hline & $\begin{array}{l}\text { Kepemimpinan } \\
\text { Islam }\end{array}$ & .079 & .218 & .078 & .360 & .722 \\
\hline & Kompensasi & .066 & .125 & .090 & .528 & .602 \\
\hline & $\begin{array}{l}\text { Pengembangan } \\
\text { Produk }\end{array}$ & .546 & .196 & .572 & 2.787 & .010 \\
\hline
\end{tabular}

a. Dependent Variable: Kinerja Karyawan

Berdasarkan dengan uji $\mathrm{R}^{2}$ yang telah dilakukan maka didapat nilai $\mathrm{R}$ squared pada tabel model summary sebesar 0,454 atau 45,4\%. Hasil ini menunjukan bahwa variabel independen yang terdiri dari kepemimpinan Islam, kompensasi, dan pengembangan produk berpengaruh terhadap variabel dependen yaitu kinerja karyawan sebesar 45,5\% kemudian sisanya dipengaruhi oleh variabel lain yang tidak digunakan dalam penelitian ini sebesar 55,5\%. 


\section{Tabel 6. Uji Koefisien determinasi}

\begin{tabular}{|l|l|l|l|l|}
\hline Model & $\mathrm{R}$ & R Square & Adjusted R Square & Std. Error of the Estimate \\
\hline 1 & $.674^{\mathrm{a}}$ & .454 & .391 & 1.9400 \\
\hline
\end{tabular}
$\begin{aligned} & \text { a. Predictors: (Constant), Kepemimpinan Islam, kompensasi, } \\
& \text { pengembangan produk }\end{aligned}$

\section{Kepemimpinan Islam terhadap kinerja karyawan.}

Dari hasil penelitian yang telah dilakukan didapatkan t hitung untuk kepemimpinan Islam sebesar 0,360 dengan nilai signifikansi 0,72 sehingga disimpulkan bahwa tidak ada pengaruh yang positif antara variabel kepemimpinan Islam terhadap kinerja karyawan. Hasil penelitian ini menunjukan bahwa gaya memimpin seorang pimpinan pada perusahaan tidak dapat mempengaruhi kinerja karyawan dikarenakan individu memiliki karakter pada dirinya yang cocok atau tidak gaya kepemimpinan. Hasil ini berbeda dengan hasil penelitian yang dilakukan oleh Endah yang menggambarkan bahwa gaya kepemimpinan Islam berpengaruh positif terhadap kinerja karyawan. Perbedaan yang ditemukan oleh peneliti dapat disebabkan karena tempat dan teori yang digunakan berbeda serta responden yang dipakai memiliki jumlah berbeda.

Kompensasi terhadap kinerja karyawan. Dari hasil penelitian yang telah dilakukan didapatkan nilai t hitung untuk kompensai sebesar 0,528 dengan nilai signifikansi 0,720 sehingga disimpulkan bahwa tidak ada pengaruh yang positif antara variabel kepemimpinan Islam terhadap kinerja karyawan. Hasil penelitian ini sejalan dengan hasil penelitian yang dilakukan oleh Emmy Ermawati dan Noer Aisyah Barlian yang menggambarkan bahwa kompensasi berpengaruh negatif terhadap kinerja karyawan secara parsial. Namun penelitian ini berbeda dengan penelitian yang dilakukan oleh Soleh Adang Saputra yang menemukan bahwa kompensasi berpengaruh positif signifikan terhadap kinerja karyawan pada perusahaan, sehingga perlu bagian perusahaan dalam memperhatikan kompensasi yang diberikan kepada karyawan. Hasil penelitian ini menunjukan bahwa kompensasi 
akan berpengaruh terhadap kinerja karyawan apabila karyawan bekerja dengan tujuan mendapatkan kompensasi semata, namun tidak akan berpengaruh apabila karyawan bekerja dengan mengharapkan ridho Allah SWT.

Pengembangan produk terhadap kinerja karyawan. Dari hasil penelitian yang telah dilakukan didapatkan nilai t hitung untuk kompensai sebesar 2,788 dengan nilai signifikansi 0,010 sehingga disimpulkan bahwa tidak ada pengaruh yang positif antara variabel kepemimpinan Islam terhadap kinerja karyawan. Penelitian ini berbeda dengan penelitian yang dilakukan oleh Samsul Haji dkk yang menunjukan bahwa terdapat pengaruh yang positif anatara pengembangan produk terhadap kinerja karyawan. Perbedaan yang ditemukan oleh peneliti dapat disebabkan karena tempat dan teori yang digunakan berbeda serta responden yang dipakai memiliki jumlah berbeda.

Pengembanga kepemimpinan Islam, kompensasi, dan pengembangan produk terhadap kinerja karyawan. Dari hasil penelitian yang telah dilakukan secara simultan didapatkan nilai $\mathrm{F}$ hitung untuk kompensai sebesar 7,219 dengan nilai signifikansi 0,001 sehingga disimpulkan bahwa secara simultan ada pengaruh yang positif antara variabel kepemimpinan Islam, kompensasi, dan pengembangan produk terhadap kinerja karyawan dengan nilai $\mathrm{r}$ sebesar 45,5\%. Penelitian ini menunjukan bahwa variabel independent pada penelitian ini mempunyai pengaruh $45,5 \%$ terhadap variabl dependen, sedangkan 55,5\% tersisa dipengaruhi oleh faktor lainnya.

\section{KESIMPULAN DAN SARAN}

Berdasarkan dari hasil penelitian dan analisis yang telah dilakukan mengenai kepemimpinan Islam, kompensasi, dan pengembangan produk terhadap kinerja karyawan Bank Pembiayaan Rakyat Syari'ah Bandar Lampung maka dapat ditarik kesimpulan 1) Kepemimpinan Islam memiliki pengaruh negatif terhadap kinerja karyawan Bank Pembiayaan Rakyat Syari'ah Bandar Lampung berdasarkan hasil uji t yang telah dilakukan oleh peneliti, dengan nilai R square sebesar 0,279 atau 27,9\%. 2) Kompensasi memiliki pengaruh negatif terhadap kinerja karyawan Bank Pembiayaan 
Rakyat Syari'ah Bandar Lampung berdasarkan hasil uji t yang telah dilakukan oleh peneliti, dengan nilai $\mathrm{R}$ square sebesar 0,137 atau $13,7 \%$. 3) Pengembangan produk memiliki pengaruh negatif terhadap kinerja karyawan Bank Pembiayaan Rakyat Syari'ah Bandar Lampung berdasarkan hasil uji $\mathrm{t}$ yang telah dilakukan oleh peneliti, dengan nilai $\mathrm{R}$ square sebesar 0,442 atau 44,29\%. 4) Kepemimpinan Islam, kompensasi, dan pengembangan produk secara simultan memiliki pengaruh positif terhadap kinerja karyawan Bank Pembiayaan Rakyat Syari'ah Bandar Lampung berdasarkan hasil uji t yang telah dilakukan oleh peneliti, dengan nilai R square sebesar 0,454 atau 45,5\%.

Adapun saran bagi penelitian berikutnya untuk dapat mempertimbangkan 1) jumlah populasi dan juga jumlah subjek dalam penelitian. 2) menambah literatur variabel lainnya yang dapat mempengaruhi kinerja karyawan.

\section{DAFTAR PUSTAKA}

Irawati, Anik. (2018). Pengaruh Stress Kerja, Motivasi Kerja, dan Kompensasi terhadap Kinerja Karyawan dengan lama kerja sebagai Variabel Moderating. Akuntability: Jurnal Ilmu Akuntansi Vol.11 No. 1 Hlm. 117- 134, P-ISSN:1979-858X, E-ISSN: 2461-1190, Doi: 10.15408/akt.VIIi/8789.

Kwarimah, Annisa Coriyani. (2018). Pengaruh Gaya Kepemimpinan terhadap KinerjaKaryawan pada Panin Dubai Syari'ah Bank KCU Asia Afrika Bandung. Prosiding Keuangan Perbankan Syari'ah, ISSN: 2460-2159

Ermawati, Emmy \& Barlian, Noer Aisyah. (2018). Pengaruh Kompensasi Langsung, Tidak langsung, dan Kompensasi Non Financial Terhadap Motivasi dan Kinerja Karyawan pada Klinik Swasta di Kab. Lumajang. Progress Conference E-ISSN $\quad 2622-304 X \quad P$ ISSN 2622-3031

Indriyati, Endah Susetyo. (2017). Pengaruh Gaya Kepemimpinan Islam, Motivasi, dan Etika Kerja Islam terhadap Kinerja Karyawan dengan Pemahaman Etka Kerja Islam. UPAWIJA DEWANTARA Vol.1 No.2, E-ISSN: 25804553, P-ISSN 2614-0888

Yozika, Ferlangga Al. (2017). Pengembangan Inovasi Produk Keuangan Dan PerbankanSyariah Dalam Mempertahankan Dan Meningkatkan Kepuasan Nasabah. Edunomika - Vol. 01, No. 02 (Agustus 2017)

Ithri, Fina Nafhatul \& Cahyono, Hendry. (2018). Pengaruh Budaya Organisasi, dan Gaya Kepemimpinan Islami terhadap Kinerja Karyawan pada BPD Jatim Syari'ah Cabang Surabaya. Jurnal Ekonomi Islam Vol. 1 No. 2, Hlm. 136-144

Hasibuan, Malayu S.P. (2008). Manajemen Sumber Daya Manusia. Jakarta: Bumi Aksara.

Halim, Jesslyn \& Andreani, Fransisca. (2017). Analisis Pengaruh Notivasi dan Kompensasi terhadap Kinerja Karyawan di Broadway Barbershop PT. Bersama Lima Putera, Agora Vol. 5 No. 1.

Kotler, Philip \& Keler, Kevin Lane. (2007). Manajemen Pemasaran Jilid 2 Edisi 12 Terjemahan. Benjamin Molan. Jakarta: Prenhalindo 
Wijayanti, Ratna \& Meftahudin. (2016). Pengaruh Kepemimpinan Islami, Motivasi, dan Kepuasan Kerja terhadap Kinerja Karyawan dengan Lama Bekerja sebagai Variabel Moderator. Jurnal PPKM III, Hlm. 185-192

Haji, Samsul. (2017). Pengaruh Orientasi Kewirausahaan, Inovasi Produk, dan Keunggulan Bersaing Terhadap Kinerja Pemasaran Usaha Cengkeh di Bawean. E-journal riset manajemen, Hlm. 83-95.

Saputra, Soleh Adang. (2018). Pengaruh Kompensasi dan Motivasi Kerja Terhadap Kepuasan Kerja serta Implikasinya Terhadap Kinerja Karyawan Dinas Pendidikan Kab. Karawang. Jurnal Manajemen dan Bisnis Kreatif.

Wacjuni. (2014). Pengarhj Orientasi Produk, Inovasi Produk, dan Kualitas Layanan Terhadap Kinerja Pemasaran dalam Upaya Mencapai Keunggulan Bersaing. Jurnal Ekonomi dan Teknik Informatika Vol.2 No.1. 